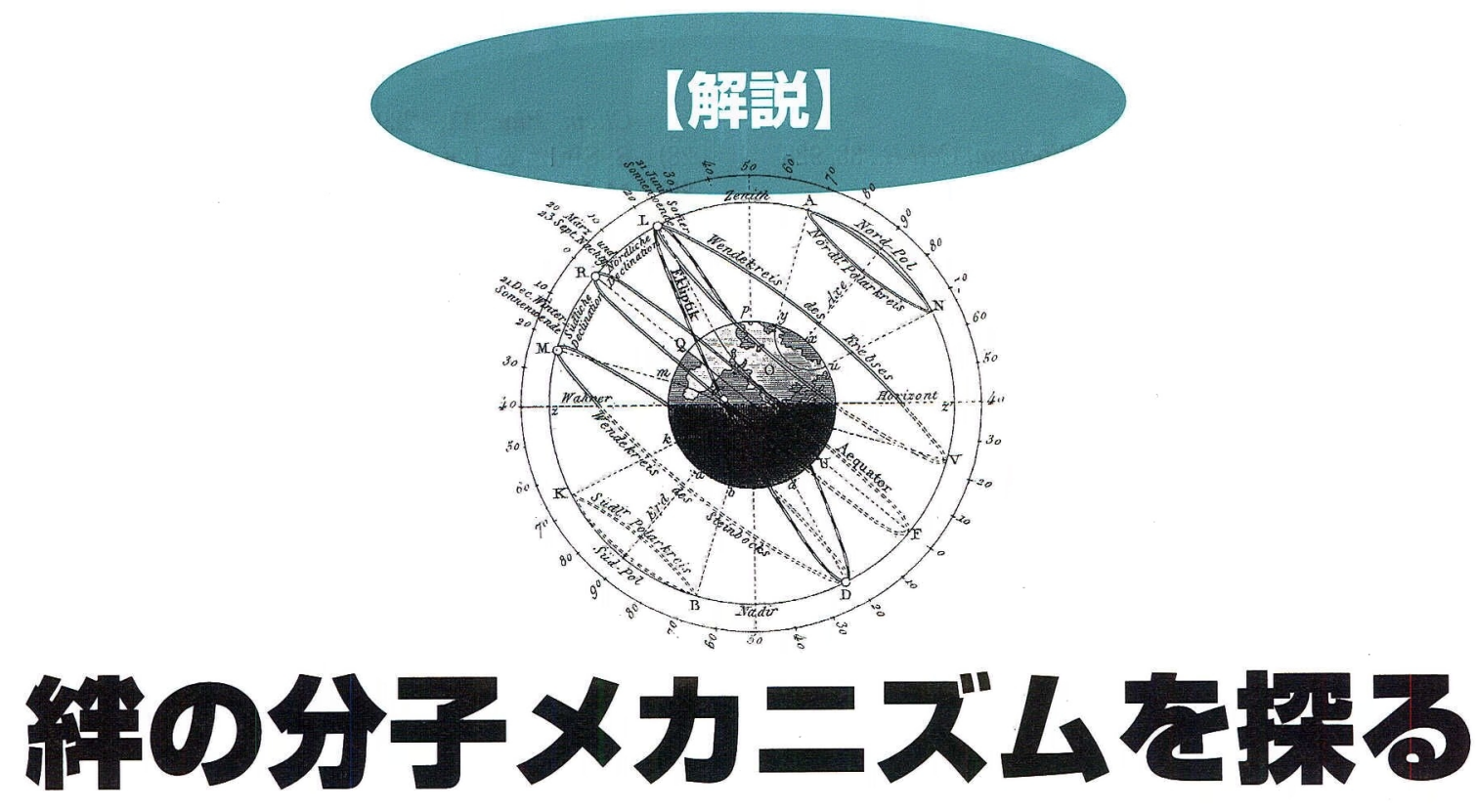

椛 秀人

哺乳類では子どもの脳 (発達脳) が環境に応じて大きく変化 すること, さらに交尾や妊娠・分娩・授乳などを契機におと なの脳 (成熟脳) も変化することが明らかになっている. こ れらの脳の変化には感受性期があり，その時期に起こる脳の 可塑的な変化によって, 親子・夫婦の絆は支えられているこ とが示されつつあり, 分子の言葉で理解することも可能に なってきた.

オランダの哲学者スピノザ (Baruch Spinoza) が「人 間は社会的な動物である」と述べたように，人類はその 誕生以来，親子や夫婦をはじめとする人と人の “絆” を 求めてきた。しかし，その複雑さのために，近年まで脳 科学の研究対象とはならなかった. 一方, 親子・夫婦の 問題は，新しい世紀を迎えてますます困難なむのとなり つつある. 愛情で結びついたはずの家族の中で, 時とし て命を奪うほどの暴力が起こる. 子どもに対するものに ついてみると, 全国の児童相談所に持ち込まれる虐待の 件数は, 年々増加の一途を辿っており, この問題への取 り組みが社会的に強く求められている. 人間の生態学的 過程がいかに複雑であるかを深く認識し理解しなければ ならないが, 人間における親子・夫婦の間の愛着行動を

Neurobiological Mechanisms Underlying Social Bonds Hideto KABA, 高知大学医学部生理学講座
理解するためには，広範囲にわたる各種動物の詳細かつ 正確な観察から学びとることが必要である。なぜかとい うと, 愛着行動は種の保存と維持に関わる基本的行動で あり，人間とその他の動物は，互いに共通した行動パ ターンを進化させてきたと考えられるからである．事 実, 子どもに反応して活性化される母親の脳の活動部位 は，人間と瓃歯類で似ていることから，哺乳類の脳には 普遍的な母性回路が存在すると考えられる ${ }^{(1)}$.

筆者らは，特定の感受性期ににおいを手がかりとして 形成される夫婦の紏, 母と仔の絆のメカニズムを分子, 細胞, システムレベルで解明することを目指してきた. 本稿では，筆者らの成果のほか他者の成果も交えて，哺 乳類における絆の分子メカニズムについて考察したい.

\section{夫婦の絆のモデル I：一雌一雄型のハタネズミ}

大草原に住むプレリー・ハタネズミは一雌一雄型であ るが，山地に住むメドー・ハタネズミは乱交型である. プレリー・ハ夕ネズミの雌は, メドー・ハ夕ネズミの雌 に比へ，側坐核などの特定部位のオキシトシン受容体の 発現密度が高い(2,3).この側坐核にオキシトシン受容体 アンタゴニストを注入すると，交尾を引き金として成立 するはずの夫婦の紏が形成されなくなる ${ }^{(4)}$. 側坐核の 
バゾプレッシン，オキシトシン：主に，視床下部室傍核 之視索上核の大細胞性 神経内分泌細胞体で合成され，下垂体後葉から血中へと放 出されるホルモン. 9 個のアミノ酸のペプチド，バゾプレッ シンは，腎臟に作用し抗利尿をもたらし，血管に作用し昇 圧させ，下垂体前葉に作用し ACTH 放出を促進させる．体 液の浸透圧の上昇, 体液量減少, 血圧低下, ある種のス卜 レス刺激（痛み，走行，焱症）で末梢血中に放出される. オキシトシンは，乳腺に作用し射乳，子宮筋に作用し子宮 を収縮させる，妊娠，分娩，吸乳，ストレス刺激で末梢血 中に放出される。バゾプレッシン，オキシトシンともに， 中枢神経系内に扔いても，大細胞性神経内分泌細胞の細胞
体・樹状突起から，あるいは小細胞性ニューロンから放出 される

グルタミン酸：グルタミン酸受容体に作用して興奮性の シナプス伝達に関与する。グルタミン酸 受容体は，それ自体がイオンチャネルの機能を有するイオ ンチャネル型（GluR）とGタンパク質を介して細胞内情報 伝達系に連結する代謝型（mGluR）とに大別される。

GluRは，さらにNMDA 型，AMPA 型，カイニン酸型と いう 3 つに分類される.

LTP：特定の頻度, たとえば高頻度に刺激することに よって, シナプス伝達効率が長期にわたって増強 される現象をいう。
ドーパミン D2 受容体の活性化も必要である ${ }^{(5,6)}$. 一方, プレリー・ハ夕ネズミの雄は, メドー・ハタネズミの雄 よりも腹側淡蒼球のバゾプレッシン受容体 V1a の発現 密度が高くなっている ${ }^{(7)}$.ここにV V1a 受容体アンタゴ ニストを注入すると，夫婦の紏が形成されなくなる ウイルスベクターを用いてプレリー・ハタネズミのV1a 遺伝子をメドー・ハタネズミの前脳部に過剩発現させる と, 乱交型のメドー・ハタネズミが一雌一雄型に一変す ることから，V1a受容体の重要性が明確に検証され た ${ }^{(9)}$.

ハ夕ネズミの夫婦の絆の神経機構に関する知見 ${ }^{(4)}$ 要 約すると，次のようになる（図 1). 交尾シグナルは腹側 被蓋野を活性化し，それによって前頭前野のドーパミン 活動を増加させる．同時に，交尾相手のにおいシグナル が嗅球を経て扁桃体内側核へ伝達される，オキシトシン は扁桃体内側核に，バゾプレッシンは外側中隔に作用し てにおいの記憶・学習を促進する，交尾シグナルはま た，雌の前頭前野と側坐核のオキシトシン濃度を増加さ せ, 雄の腹側淡蒼球のバゾプレッシン濃度を増加させ る. 外側中隔と腹側淡蒼球のバゾプレッシン作動性神経

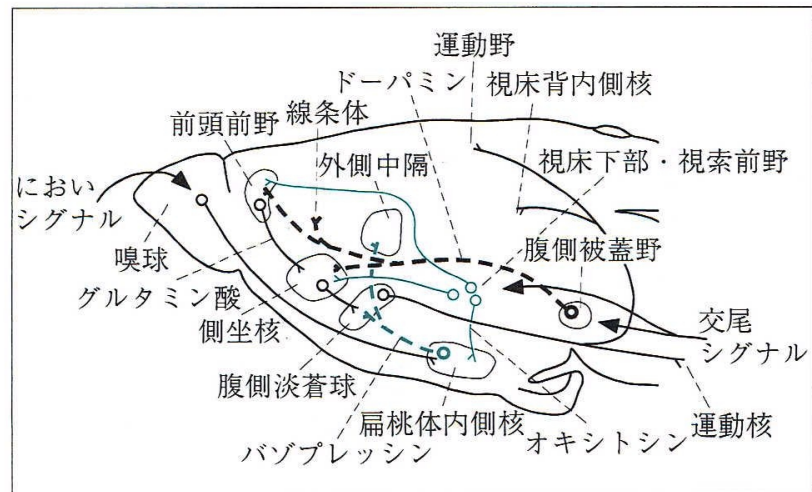

図1・ハタネズミにおける夫婦の絆の神経回路

文献 (4) より改変
の細胞体は扁桃体内側核などに由来する。側坐核，扁桃 体内側核, 前頭前野へのオキシトシン作動性神経の投射 は同定されていないが，その神経の細胞体は視床下部・ 視索前野に由来しうる．前頭前野から側坐核へのグル夕 ミン酸作動性神経の投射は, 夫婦の絆の形成を促進す る。側坐核あるいは腹側淡蒼球におけるドーパミン系と オキシトシン系(雌)あるいはバゾプレッシン系(雄) との 同時の活性化は交尾相手への嗜好の発達をむたらす. 腹 側淡蒼球は側坐核の主要な出力部であり, 視床背内側核 や大脳皮質運動野, 中脳の運動核への投射を介して強化 刺激に応答して運動出力を修飾する。

夫婦の絆のモデル II : 雌マウスに形成される交配 雄のフェロモンの記憶

\section{1. フェロモン記憶の特徵}

多くの哺乳動物は，2つの主要な嗅覚情報処理系を所 有している。一つは主嗅覚系 (単に嗅覚系とも呼ぶ)，む う一つは鋤鼻 (副嗅覚) 系と呼ばれている（図 2)。雌マ ウスを交尾後 24 時間以内に交配雄から引き離し, 他系 統の雄と一緒にしておくと妊娠が阻止される（図 3)。こ の効果は，雄の尿でも再現されるので，尿に含まれる フェロモンの作用である。このフェロモンによる妊娠阻 止現象は，発見者の名にちなんでブルース効果と呼ばれ ている(11)．ブルース効果は鋤鼻系の働きで起こる，すな わち，鋤鼻器で受容された雄のフェロモン情報は，まず 副嗅球で中継され, その後, 扁桃体, 分界条, 内側視索 前野を順次経由して, 最終的に視床下部弓状核の隆起漏 斗系ドーパミン神経分泌細胞を興禽させる ${ }^{(10)}$. したがっ て，プロラクチン分泌抑制因子であるドーパミンの下垂 体門脈血中への放出量が増加するため, 下垂体前葉から のプロラクチンの分泌が低下する，褵歯類の場合，プロ ラクチンは黄体刺激作用を有しているので，このホルモ ンの低下は黄体からのプロゲステロンの分泌低下を招 

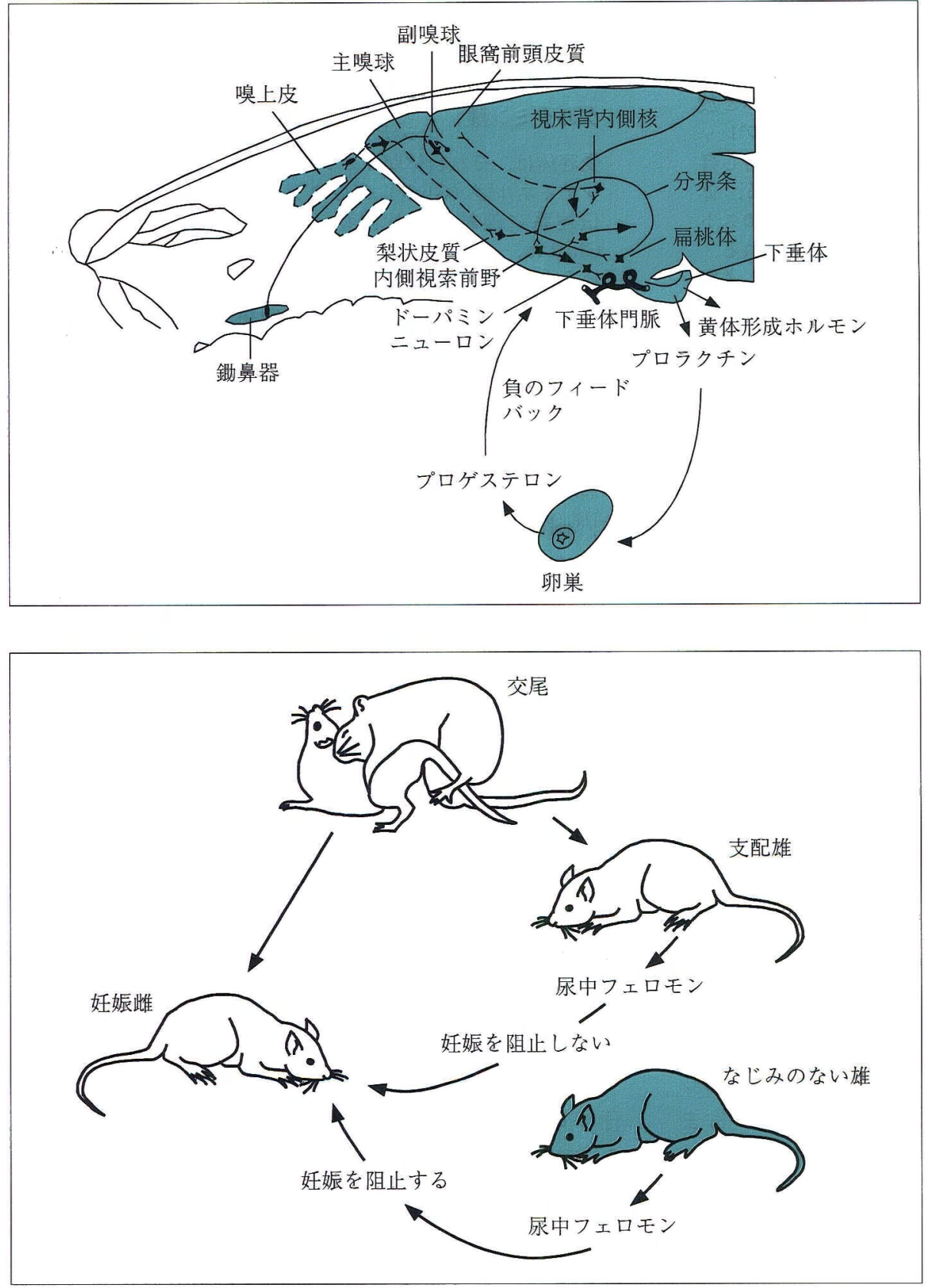

図 2ロ2つの嗅覚系：主嗅覚系と 鋤鼻系

主嗅覚系を破線で，䤮鼻系を実線で 示す。文献（10）ょり改変
図 3 ロ雌マウスに形成される交配 雄のフェロモンの記憶

雄マウスの尿中フェロモンには元 来, 雌に発情をむたらす作用があ る. 交尾直後の感受性期に数時間, 雌マウスがこのフェロモンを搝ぐ と，その後はこのフェロモンによる 発情が起こらなくなる。つまり，妊 娠は保障されることになる。文献 （10）より改変
く.この一連の変化が, 受胎して間もない雌で起これば 着床が期げられ，妊娠阻止に帰着する.

一方，交尾して間もない雌マウスが数時間後に交配雄 から離され，24 時間後に雄のケージに戻されても，妊娠 は阻止されない，交配雄の尿にも妊娠阻止を惹起する フェロモンは含まれている。それにもかかわらず，交配 雄のフェロモンが妊娠を阻止できないのは, 実は雌マウ スが交尾刺激を引き金としてこのフェロモンを記憶 し(11), この記憶によって, そのフェロモン情報の視床下 部への伝達を阻止しているからである。すなわち，この 記憶は妊娠の保障という生存価の高い働きを担っている
わけである.

\section{2. 感受性期, 記憶の保持と消去}

フェロモン記憶は, 雌を雄のフェロモンに曝露させた だけでは形成されず，記憶形成には交尾刺激が必要であ $ろ^{(12)}$. しかし，交尾完了と同時に記憶が成立するわけで はない，記憶形成には，雌を雄のフェロモン*に 4.5〜6 時間曝露させる必要がある(13). しかも, 交尾直後, 雌を

*フェロモンは主要組織適合抗原複合体リガンドペプチドである との知見が報じられている. 
雄のフェロモンから離し，6時間経ってからフェロモン に曝露させても記憶は形成されない.すなわち, 記憶形 成には, 交尾直後から $4.5 \sim 6$ 時間の曝露が必要であり, この期間が要するに記憶形成の感受性期ということにな る.一度形成された記憶は, 少なくとも 30 日間は保持さ れる(14). すなわち，この記憶は長期記憶として蓄えられ る. 一方, この記憶は妊娠によって積極的に消去され $ろ^{(14)}$.

\section{3. 記憶の貯蔵庫：副嗅球}

このフェロモン記憶は脳のどの神経回路が関わって形 成され，どこに蓄えられるのであろうか. 近交系マウス を使う限り，妊娠阻止に関して雌マウスが識別できるの は系統差である．このように系統間で異なるにおいと いった複雑なものの認識は, 主嗅球から入力を受けてい る大脳皮質でなされる，亡考えるのが当然かもしれな い. しかし, 主嗅覚系が妊娠阻止に関わるフェロモンの 認識と何らかの関係をむつ, という証拠は得られていな い. 鼻腔粘膜嗅上皮 (主嗅覚系) の選択的破壊によって, 正常雄の尿のにおいと去勢雄のそれとの識別は著しく阻 害されるが, 妊娠が交配雄ではなく, なじみのない雄 (交配雄とは系統の異なる雄) の尿によって阻止される という現象はまったく影響を受けない(15). 海馬むまた嗅 覚情報を受け取るが, 海馬を破壊してもこのフェロモン の認識は影響を受けない(16). したがって, 交尾に続いて 起こるフェロモンの認識は, 発情（妊娠阻止）をむたら す鋤鼻系の働きによると考えられる，それでは，鋤鼻系 投射部のどこが交配雄のフェロモンの認識・記憶に必要 なのだろうか。

筆者らは, 記憶形成の感受性期に鋤鼻系投射部へ局所 麻酔薬を注入して, この感受性期のフェロモン情報伝達 を一時的に遮断するという可逆的方法で, この問題を検 討した ${ }^{(17)}$. 最初の中継部位である副嗅球へ注入して, そ れ以降への情報伝達を遮断すると, 記憶障害が起こる が, 次の中継部位である扁桃体へ注入して, それ以降へ の情報伝達を遮断しても記憶障害は起こらなかった。こ の実験結果は, フェロモン情報が扁桃体より前の鋤鼻系 中継部位まで伝えられると記憶として蓄えられ得ること を示している. 扁桃体より前の中継部位というのは唯一 副嗅球しかない.

この記憶形成には, 副嗅球へのノルアドレナリン作動 性線維の入力の働きが不可欠である. 交尾前に副嗅球の ノルアドレナリン作動性神経終末を 6-ヒドロキシドー パミンで選択的に破壊して扔くと, なじみのない雄の フェロモンはもちろんのこと, 交配雄のフェロモンに
よっても妊娠が阻止されてしまう(13). また，交尾のとき の腟刺激は嗅球のノルアドレナリンの代謝回転率を有意 に増加させる ${ }^{(13)}$. この増加は刺激後 3 時間持続し, 記憶 形成に必要なフェロモン曝露時間と対応している，さら に, 記憶形成には, このノルアドレナリンの放出の増大 により活性化される $\alpha$ 受容体*が必要である(18). した がって, 交尾刺激は副嗅球におけるノルアドレナリン放 出の増大と $\alpha$ 受容体の活性化をむたらすことにより, 記 憶形成へと導くものと推察される.

長期記憶には新たなタンパク質の合成が必要であると の考えが支配的である.フェロモン記憶が形成されるた めには, 交尾直後から約 6 時間のフェロモン曝露が必要 であることはすでに述べたが，この期間の前半のタンパ ク質合成阻害でも，この期間以降のタンパク質合成阻害 でも無効であるが，この期間の後半のタンパク質合成阻 害だけが記憶形成を妨げる(17)。このことは, 記憶形成に タンパク質合成が必要であり, かつその時間帯が狭いこ とを示している。

以上の一連の実験結果は, 副嗅球が認識過程のみなら ず記憶を蓄える場として重要であることを示してい $ろ^{(12)}$.

\section{4. 副嗅球におけるノルアドレナリンの作用}

交尾刺激によって放出され記憶形成へと導くノルアド レナリン（NA）は, 副嗅球内シナプス伝達にいかなる効 果を及ぼすのであろうか? 鋤鼻器で受容されたフェロ モン情報は副嗅球の僧帽細胞へ伝達される.この僧帽細 胞は次の中継核である扁桃体へインパルスを送るが, こ のインパルスの頻度とパターンは副嗅球内の情報処理機 構によって制御されている。 その主たる場は, 僧帽細胞 の主樹状突起が顆粒細胞とつくっている樹状突起どうし の相反性相互シナプスである（図 4).フェロモン受容に 続いて興奮した僧帽細胞は, グルタミン酸 (用語解説) を放出して顆粒細胞を興奮させる．興奮した顆粒細胞 は, 神経伝達物質の GABA ( $\gamma$-アミノ酪酸) を放出して 僧帽細胞を抑制する，すなわち，中継ニューロンである 僧帽細胞は顆粒細胞から負のフィードバック制御を受け ているわけである.

筆者らは, 副嗅球スライス標本を調製して, 僧帽細胞 樹状突起から顆粒細胞樹状突起への興奮性シナプス伝達 およびその可塑性におけるノルアドレナリンの効果を電 気生理学的に解析した ${ }^{(19)}$. 僧帽細胞の軸索 (外側嗅索)

*ノルアドレナリンの受容体は, その薬理学的特性により $\alpha$ ある いは $\beta$ などの種類に分類され，それらはさらに $\alpha_{1}, \alpha_{2}$ などいくつ かの種類に細分される. 


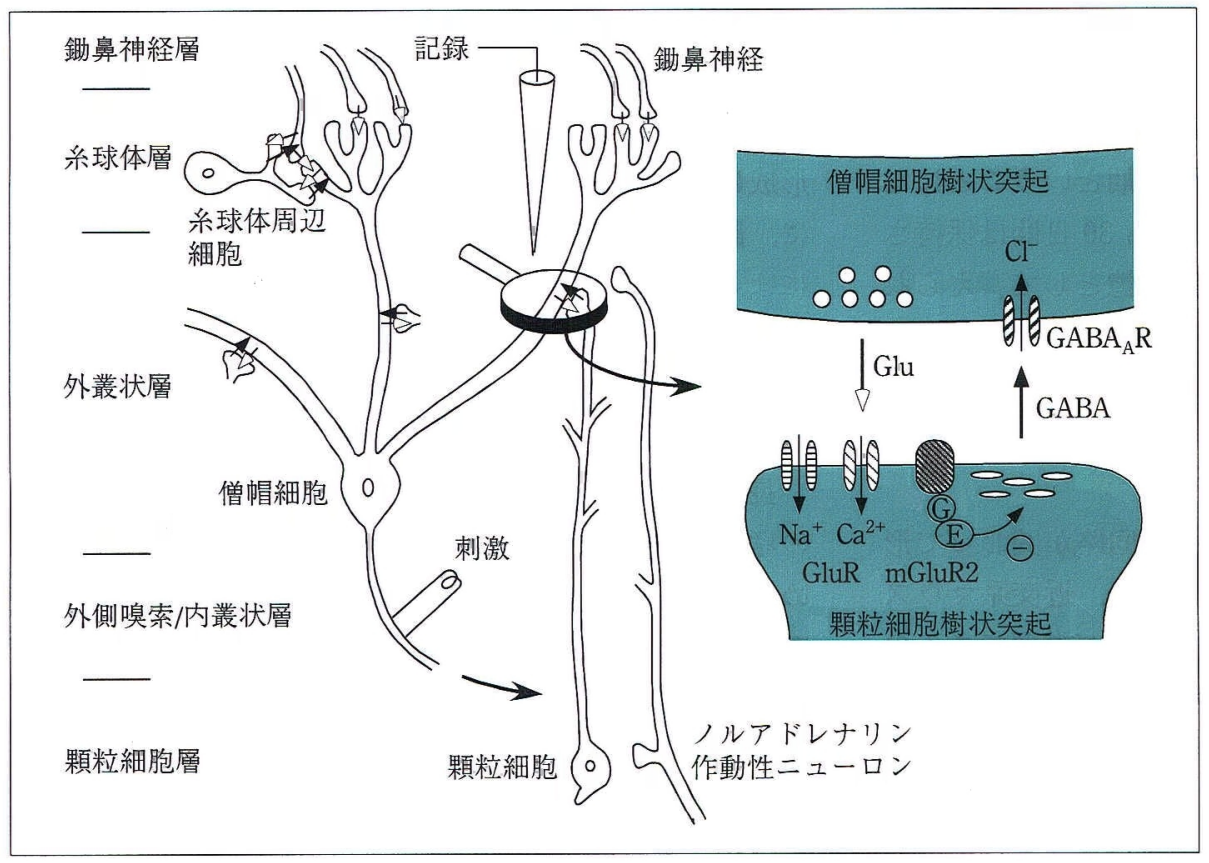

図 4 -副嗅球内の主要神経回路と 電気生理学的実験のプロトコール 右に僧帽細胞と顆粒細胞の間に形成 されている樹状突起どうしの双方向 性シナプスを示す. 白矢印は興奮性 シナプスを, 黒矢印は抑制性シナプ スを表わしている. GABA の放出 を抑制する信号路をマイナス@付き の矢印で示す. Glu：グルタミン 酸, GluR：イオンチャネル型グル タミン酸受容体, mGluR2 : 代謝型 グルタミン酸受容体, $\mathrm{GABA}_{\mathrm{A}} \mathrm{R}$ : $\mathrm{GABA}_{\mathrm{A}}$ 受容体, $\mathrm{G}: \mathrm{G}$ タンパク 質, $\mathrm{E}:$ 細胞内エフェクター. 文献 （10）より改変

を電気刺激すると, 顆粒細胞の興奮性シナプス後電位 （フィールドEPSP; fEPSP）を反映した陰性フィールド 電位が記録される. 外側暞索を比較的低頻度で長時間 $(10 \mathrm{~Hz}, 20$ 発，3 分間隔で 20 回) 刺激すると, fEPSP の 長期増強 (long-term potentiation : LTP) (用語解説) が誘導された。一方, 短時間高頻度刺激 $(100 \mathrm{~Hz}, 100$ 発，3分間隔で 4 回）はLTP の誘導に有効ではなかっ た.これらの結果は, フェロモン記憶の形成に数時間の フェロモン懪露が必要であることと符合する。この LTP は NMDA (N-メチル-D-アスパラギン酸) 受容体に 依存して誘導された。 フェロモン記憶に不可欠なノルア ドレナリンは $\alpha_{2}$ 受容体を介して LTP の発現に促進的に 作用した.この結果は, 行動薬理学的結果よよく符合し ており，LTPがフェロモン記憶の基礎過程であるとの 見地を支持している.

僧帽細胞から顆粒細胞へのグルタミン酸作動性シナプ スにおけるLTPは, このシナプスの形態学的変化を伴 うことが考えられる. 事実, 電子顕微鏡を用いてシナプ スの微細形態を観察すると，この変化が捉えられる ${ }^{(20)}$. すなわち, 記憶を形成していない対照群に比較して記憶 形成群では, 僧帽細胞から顆粒細胞への興奮性シナプス の後膜肥厚のサイズが増大しているという結果である.

顆粓細胞のグルタミン酸受容体の活性化を引き金とし て, その下流にどのような細胞内の分子カスケードが存 在するかは，まだ不明であるが，記憶形成へと導くいく つかの情報分子, たとえばカルモジュリン (21), タンパク 質キナーゼ(21), 一酸化窒素 ${ }^{(22,23)}$, 最初期遺伝子 ${ }^{(24)}$ など
が考えられている. Brennan ら ${ }^{(25)}$ は, 記憶形成と副嗅 球内神経伝達物質の放出との相関性についてマイクロダ イアリシス法を用いて検討し, 記憶形成前に比較して, 記憶形成とともに GABA の放出が増加していくことを 認めている。一方, グルタミン酸の放出は増加しない。

\section{5. フェロモン記憶のシナプス・分子メカニズム}

僧帽細胞から顆粒細胞への興奮性シナプスの可塑的変 化がどのように誘導されるのであろうか？ その変化が どうして妊娠を保障することになるのであろうか？ 交 尾前, すなわち記憶形成前にフェロモン受容により興奮 した僧帽細胞はこれと対をなす顆粒細胞からフィード バック抑制を受けることによって特定の発火パターンを 形成し，この情報を次の中継核へ送り,ひいては内分泌 変化を誘起する. このときの内分泌変化は, プロゲステ ロンの低下による発情の誘起である. 交尾刺激によって 放出されたノルアドレナリンは僧帽細胞の $\alpha_{2}$ 受容体の 活性化, これに続く電位感受性 $\mathrm{Ca}^{2+}$ チャネルの抑制を 介してグルタミン酸の放出を抑制する（図 5)。このとき 交配雄のフェロモンを受容すると, 僧帽細胞の興奮に応 じて顆粒細胞に発生する興奮性シナプス後電位の後の狭 い時間帯に顆粒細胞の発火が忠実に起こる.ノルアドレ ナリンが作用しないと, 顆粒細胞は脱分極し過ぎて $\mathrm{Na}^{+}$ チャネルの不活性化過程から回復できず, 発火の忠実度 が著しく低下する．この僧帽細胞から顆粒細胞への数時 間にわたる忠実度の高いシナプス伝達が，むろもろの情 報分子を駆動して，このシナプスに可塑的な変化をもた 


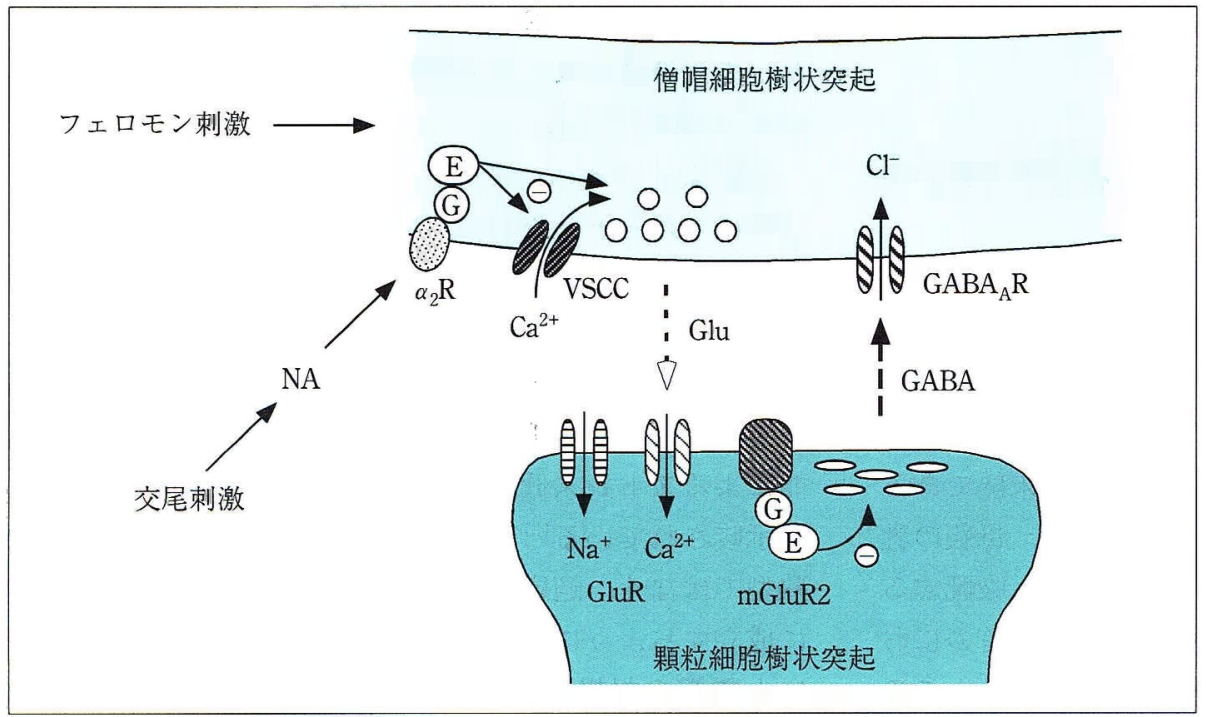

図 5-LTP 誘導のメカニズム

$\mathrm{NA} ：$ ノアドレナリン, $\alpha_{2} \mathrm{R}: \alpha_{2}$ アドレナリン受容体, VSCC：電位 感受性カルシウムチャネル, Glu： グルタミン酸, GluR：イオンチャ ネル型グルタミン酸受容体, mGluR2：代謝型グルタミン酸受容 体, $\mathrm{GABA}_{\mathrm{A}} \mathrm{R}$ : $\mathrm{GABA}_{\mathrm{A}}$ 受容体, $\mathrm{G}: \mathrm{G}$ タンパク質, $\mathrm{E}$ : 細胞内エ フェクター. 本文参照.

らす。この変化はさらに，メカニズムは不明であるが, GABA の放出の増加へと導く. 記憶形成後, この僧帽細 胞一顆粒細胞間シナプスを刺激する交配雄のフェロモン 信号は, 選択的に抑制され, 妊娠は保障される. 一方, なじみのない雄のフェロモンは，このようなシナプス変 化が生じていない僧帽細胞一顆粒細胞間シナプスを刺激 して流産をひき起こす。

\section{母と仔の絆のモデル I : 母ヒツジによるわが子の認 識}

ヒツジは群れで生活し，かつ季節繁殖動物であるの で，春になると多くの子どもが群れに存在することにな る. 子ヒツジは $2 \sim 4$ 週齢くらいにならないと母親を認 識できないので，どの母親にも近づき乳を飲もうとす る.しかし，母ヒツジはわが子のみを受け入れ，他の子 を拒絶する．この拒絶行動は自分の子の生存を保障する ことになり，適応的意義を有している，この拒絶行動は， 子ヒツジの毛や皮膚のに扔いが主嗅覚系で受容・処理さ れて誘起される．搝球を除去したり，鄓上皮を破壊する と母ヒツジはどの子どもむ受け入れてしまう。このこと は，母ヒツジがにおいを搝げなくても母性行動自体は起 こるが，においを搝げないとわが子に対する選択性が失 われることを示している。

妊娠中のヒツジは子どあのにおいよりは餌のにおいに 興味を示す。しかも，子どものにおいは母性行動に抑制 的に作用する．ところが，分婏を契機に母ヒツジは根本 的に変わり，餌よりは自分の子どものにおいに興昧を示 すようになる。これらの変化は，嗅球の僧帽細胞のにお い応答にも認められる ${ }^{(26)}$. 妊娠中のヒツジの僧帽細胞は 子どものに扔いにほとんど応答しないが，分婏後は，わ
が子のにおいに選択的に応答する僧帽細胞が記録される ようになる，母ヒツジのわが子に対する選択性は，分婏 時の産道刺激によって賦活された青斑核ノルアドレナリ ン作動性神経および視床下部室傍核オキシトシンニュー ロンがそれぞれノルアドレナリンおよびオキシトシ ン(27)を主嗅球において放出し, 主嗅球の僧帽細胞と顆粒 細胞之の間の相反性相互シナプスに可塑的変化を誘導す ることにより成立すると考えられている ${ }^{(28,29)}$. ノルアド レナリンは僧帽細胞を脱抑制する。この脱抑制により NMDA 受容体が活性化され, 一酸化窒素が放出され る ${ }^{(28)}$ 。一酸化窒素はグルタミン酸の放出を増大させ, 僧 帽細胞と顆粒細胞との間の相反性相互シナプスに可塑的 変化を促進するというメカニズムが提唱されてい $3^{(28,29)}$.オキシトシンもノルアドレナリンの放出を增大 させ, 可塑性の誘導に関わる ${ }^{(30)}$. 分娩後は, わが子のに おいに応答して主嗅球において放出されるグルタミン酸 と GABA の量がともに増加するが，グルタミン酸より GABA の増加が大きい(26)，母ヒツジがわが子のにおい を認識・記憶するときに活性化されることが証明されて

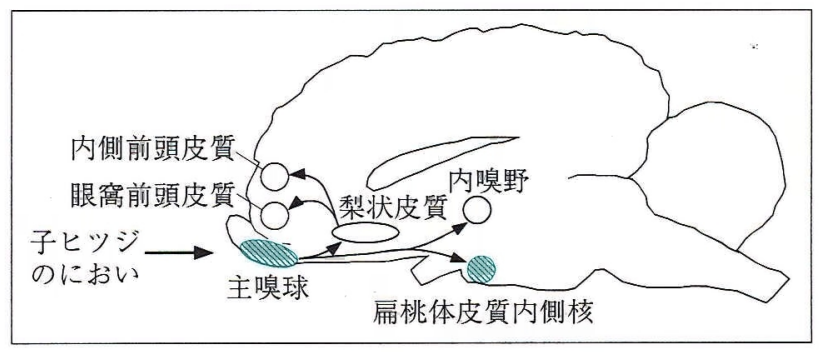

図 6ロ母ヒツジがわが子のにおいを認識・記憶するときに活 性化される脳部位

わが子の認識・記憶に関わることが証明されている部位をコバ ルト色で示す. 文献 $(29)$ より改変 
いる脳部位は, 主嗅球のほか, 扁桃体皮質内側核であ る(31) (図 6).

\section{母と仔の絆のモデル II : 新生仔におけるにおいの 学習}

生後間もない時期に成立するにおいの古典的条件づけ がウサギとラットで研究されている(32 34). 両者とも就 巣性の哺乳動物なので，生まれたときは耳も聞こえない し, 目も見えない，子どもは主に嗅覚と体性感覚に頼っ て外部環境との関係を発達させる．子どもは未熟である ため母親による世話を相当必要としているが，母親の乳 首がどこにあるかを定め，それにたどりつき，吸乳する といった行動は子にゆだねられている，子は乳首のにお いを手がかりとしてこの一連の行動を成し遂げる．この においは主嗅覚系で受容・処理され，乳首を探す行動を 触発する. 生後間むない時期ににおいの学習を促す感受 性期が存在する。ひとたび乳首のにおいに対する学習が 成立すると, 子はこのに扔いに対して愛着を獲得し, こ のにおいに反応して乳首を探す行動を強く起こすことに なる. ウサギの場合, 授乳中の口周辺の触刺激が無条件 刺激として作用している. ラットの場合，母親が子をな めるといった体性感覚刺激が無条件刺激となる．実験的 には, 刷毛による体幹の摩擦, 尾の圧迫, フットショッ クなどの体性感覚刺激を無条件刺激とするにおいの古典 的条件づけが解析されている.

事実, 生後 11 日目ににおいと電撃を 30 分間, 1 回対 提示するだけで，このにおいに対する嫌悪学習が成立す る.このにおい学習は, 電撃により賦活されたノルアド レナリン神経の働きを引き金として, 主嗅球の僧帽細胞 と顆粒細胞の相反性相互シナプスが深く関わり, 転写因 子 CREB (cyclic AMP response element-binding protein) の発現とそのリン酸化を介して成立することを筆 者らは示してきた ${ }^{(35,36)}$. しかも, 主嗅球の CREB の発現 は長期記憶にのみ必要で短期記憶には必要ではないとの 知見が得られた。この知見は，CREB が短期記憶を長期 記憶へ移行させる分子スイッチとして働いていることを 示すとともに，主嗅球がまさに記憶を蓄える場であるこ とを示唆している. CREBのリン酸化には多くのキナー ゼが関わることが知られている. extracellular-signal regulated kinase (ERK) は mitogen-activated protein kinase (MAPK) サブファミリーの一員であり, MAPK/ ERK キナーゼ (MEK) によってリン酸化される。に いと電撃の対提示のときに MEK 阻害剂を主嗅球へ注入 すると，におい学習が阻害され，かつCREB のリン酸化 も有意に低下することから，に抢い学習の成立に主嗅球
の MAPK/ERK-CREB 経路が重要であることが判明し た. また筆者らは，この学習の電気生理学的相関である LTP も捉えている.

興味深いことに，においと電撃の対提示を生後 10 日 以降に与えると，そのに扔いに対して嫌悪学習が成立す るが, 生後 8 日以内に与えると, 嗜好学習が成立する. 電撃との対提示でもにおいの嗜好学習が成立する感受性 期は，青斑核ノルアドレナリンニューロンの活動の六進 のほか, 血中コルチコステロンの低濃度と扁桃体の低機 能によるストレス低反応性によって維持されていること が示唆されている ${ }^{(37 \sim 40)}$.つまり, 新生仔脳は成熟脳の未 熟型ではなく, 適応戦略として母親への愛着形成が確実 に成立するように組織化されていると考えられる，にお いと電撃の対提示によりにおいの嗜好学習が成立する か，あるいは嫌悪学習が成立するかのスイッチングがコ ルチコステロンの投与あるいは除去（副腎摘出）によっ て操作できることから，血中コルチコステロン濃度が増 加し，それによって扁桃体が活性化されると，電撃との 対提示によりにおいの嫌悪学習が成立するようになると 考えられる.

\section{人と人の絆}

人之人の社会的相互関係の処理に関わる神経回路を同 定するための興味深い解析が行なわれている ${ }^{(41,42)}$. それ は,アニメーションを見ている間の脳の活動を評価した むのである. アニメーションは 2 個の三角形がスクリー ンでランダムに動き回るもの，ゴールに向かって動くも の，ある意図をむって相互に動くものの 3 種類である. 3 番目のアニメーションを見ると，動きのヒントだけか ら三角形の社会的な意味を理解することができる。こう した研究から，社会的な意味を理解するときに活動する 紡錘回の外節, 上側頭溝, 扁桃体, 正中前前頭皮質を含 む神経ネットワークが浮かび上がってきた．社会的な洞 察力が欠如し，コミュニケーションが障害される自閉症 者は, これらの領域のすべてで健常者に比べて神経活動 が少なく, 動いている三角形の社会的な意味が理解でき なかったのではないかと推察される.

人の社会的なつながりと神経ペプチドとの関係が知ら れている．性交時に男女とも血中オキシトシン濃度が増 加する ${ }^{(43,44)}$. 男性は, 血中バゾプレッシン濃度む増加す る ${ }^{(45)}$. 帝王切開で出産した母親は, 正常分婏で出産した 母親よりも授乳中のオキシトシンの分泌量が少なく，子 之の社会的なつながりが弱い(46). 分婏後 1 時間以内に授 乳すると, 母子の絆の形成が促進される ${ }^{(47)}$. 孤児院で育 
てられた子どもは，家庭で育てられた子よ゙もより屯尿中 のオキシトシンとバゾプレッシンの濃度が低い( ${ }^{(48)}$. 自閉 症の子どもは血中オキシトシン濃度が低い(49)．この低值 は，翻訳後のプロホルモンをホルモンにする酵素の変異 が関わっている可能性がある ${ }^{(50)}$. 自閉症やアスペルガー 症候群の成人にオキシトシンを投与すると，多動が減少 する ${ }^{(51)}$. オキシトシンは人と人の信頼関係を深める ${ }^{(52)}$. 以上の知見は，オキシトシンやバゾプレッシンが親子・ 夫婦の絆の形成に深く関わっていることを示唆してい る.

新生児は母親のにおいに嗜好反応を示すが，この反応 は分婏後の母子対面が 1 時間遅れても弱まる ${ }^{(53,54)}$ 。一 方，母親もわが子のにおいを弁別する力は分婏直後ほど 高い(55, 56)．そのため分娩直後，あるいはできるだけ速や かな母子対面が重要とされている。 しかし，人は高い適 応能力をもち，その絆も動物のように単純ではない，多 くの要因が関わり，長期に渡る過程を経て形成される。 むしも子が未熟児であったり疾病をもっていたために母 子の分離を余儀なくされてむ，その後それを克服して紏 を形成していく，いわば安全機構の回路をむっているら しい.

*

紏を支える脳の機能は，複数の感覚情報処理と複雑な 運動応答のほか, 感覚入力を運動出力へと連結させる注 意や記憶，社会的認知，最む特徵的な動機づけなどの認 知過程を含む.これを理解するためには，分子から細胞， 回路, システムまでを統合的にとらえ，多角的に研究を 推進していく必要がある，さらには，基礎研究の成果を 踏まえ, 臨床医学への応用のためのトランスレーショナ ルリサーチの推進とその方法論の確立が望まれる.

\section{文献}

1) C. H. Kinsley \& K. G. Lambert: Sci. Am., 294, 72 (2006).

2) T. R. Insel \& L. E. Shapiro:Proc. Natl. Acad. Sci. USA, 89, 5981 (1992).

3) T. R. Insel \& L. J. Young: Nature Rev. Neurosci., 2, 129 (2001).

4) L. J. Young \& Z. Wang: Nature Neurosci., 7, 1048 (2004).

5) B. Gingrich, Y. Liu, C. Cascio, Z. Wang \& T. R. Insel : Behav. Neurosci., 114, 173 (2000).

6) Y. Liu \& Z. X. Wang: Neuroscience, 121, 537 (2003).

7) T. R. Insel, Z. Wang \& C. F. Ferris : J. Neurosci., 14, 5381 (1994).

8) M. M. Lim \& L. J. Young : Neuroscience, 125, 35 (2004).

9) M. M. Lim, Z. Wang, D. E. Olazabal, X. Ren, E. F. Terwilliger \& L. J. Young: Nature, 492, 754 (2004).

10) H. Kaba \& S. Nakanishi : Rev. Neurosci., 6, 125 (1995).

11) E. B. Keverne : Trends Neurosci., 6, 381 (1983).
12) P. Brennan, H. Kaba \& E. B. Keverne: Science, 250, 1223 (1990).

13) A. E. Rosser \& E. B. Keverne:Neuroscience, 15, 1141 (1985).

14) H. Kaba, A. E. Rosser \& E. B. Keverne : Neuroscience, 24, 93 (1988).

15) A. Lloyd-Thomas \& E. B. Keverne : Neuroscience, 7, 907 (1982).

16) R. Selway \& E. B. Keverne:Physiol. Behav., 47, 249 (1990).

17) H. Kaba A. Rosser \& E. B. Keverne: Neuroscience, 32, 657 (1989).

18) H. Kaba \& E. B. Keverne : Neuroscience, 25, 1007 (1988).

19) G.-Z. Huang \& H. Kaba:Neurosci. Res., Suppl., 25, S74 (2001).

20) M. Matsuoka, H. Kaba, Y. Mori \& M. Ichikawa : NeuroReport, 8, 2501 (1997)

21) H. Nakazawa, H. Kaba, T. Higuchi \& S. Inoue : Neuroscience, 69, 585 (1995).

22) C. O. Okere, H. Kaba \& T. Higuchi : Neuroscience, 71, 349 (1996).

23) C. O. Okere \& H. Kaba : Eur. J. Neurosci., 12, 4552 (2000).

24) P. A. Brennan, D. Hancock \& E. B. Keverne : Neuroscience, 49, 277 (1992).

25) P. A. Brennan, K. M. Kendrick \& E. B. Keverne : Neuroscience, 6, 1075 (1995).

26) K. M. Kendrick, F. Lévy \& E. B. Keverne : Science, 256, 833 (1992).

27) F. Lévy, K. M. Kendrick, J. A. Goode, R. GuevaraGuzman \& E. B. Keverne : Brain Res., 66, 197 (1995).

28) K. M. Kendrick, A. P. C. Da Costa, K. D. Broad, S. Ohkura, R. Guevara, F. Lévy \& E. B. Keverne: Brain Res. Bull., 44, 383 (1997).

29) F. Lévy, M. Keller \& P. Poindron : Horm. Behav., 46, 284 (2004).

30) F. Lévy, R. Guevara-Guzman, M. R. Hinton, K. M. Kendrick \& E. B. Keverne : Behav. Neurosci., 107, 662 (1993).

31) M. Keller, G. Perrin, M. Meurisse, G. Ferreira \& F. Lévy : Eur. J. Neurosci., 20, 3433 (2004).

32) R. Hudson: Curr. Opin. Neurobiol., 3, 548 (1993).

33) D. A. Wilson \& R. M. Sullivan : Behav. Neural Biol., 61, 1 (1994).

34) R. M. Sullivan \& D. A. Wilson : Learn. Mem., 10, 1 (2003).

35) J.-J. Zhang, F. Okutani, S. Inoue \& H. Kaba:Neuroscience, 117, 707 (2003).

36) J.-J. Zhang, F. Okutani, S. Inoue \& H. Kaba : Neuroscience, 121, 9 (2003).

37) R. M. Sullivan, M. Landers, B. Yeaman \& D. A. Wilson: Nature, 407, 38 (2000).

38) S. Moriceau \& R. M. Sullivan:J. Neurosci., 24, 1182 (2004).

39) S. Moriceau \& R. M. Sullivan : Behav. Neurosci., 118, 274 (2004).

40) S. Moriceau \& R. M. Sullivan:Dev. Psychobiol., 47, 230 (2005).

41) F. Castelli, F. C. Frith, F. Happé \& U. Frith : Brain, 125, 1839 (2002)

42) U. Frith : Neuron, 32, 969 (2001).

43) S. Uckert, A. J. Becker, B. O. Ness, C. G. Stief, F. Scheller W. H. Knapp \& U. Jonas: World J. Urol., 20, 323 (2003).

44) W. Blaicher, D. Gruber, C. Bieglmayer, A. M. Blaicher W. Knogler \& J. C. Huber: Gynecol. Obstet. Invest., 47, 
125 (1999).

45) M. R. Murphy, J. R. Seckl, S. Burton, S. A. Checkley \& S. L. Lightman : J. Clin. Endocrinol. Metab., 65, 738 (1987).

46) E. Nissen, P. Gustavsson, A. M. Widstrom \& K. UvnasMoberg: J. Psychosom. Obstet. Gynaenol., 19, 49 (1998).

47) M. M. McCarthy \& M. Altemus: Mol. Med. Today, 3, 269 (1997).

48) A. B. Wismer Fries, T. E. Ziegler, J. R. Kurian, S. Jacoris \& S. D. Pollak : Proc. Natl. Acad. Sci. USA, 102, 17237 (2005).

49) C. Modahl, L. Green, D. Fein, M. Morris, L. Waterhouse,

C. Feinstein \& H. Levin : Biol. Psychiatry, 43, 270 (1998).

50) L. Green, D. Fein, C. Modahl, C. Feinstein, L. Water- house \& M. Morris: Biol. Psychiatry, 50, 609 (2001).

51) E. Hollander, S. Novotny, M. Hanratty, R. Yaffe, C. M. DeCaria, B. R. Aronowitz \& S. Mosovich : Neuropsychopharmacology, 28, 193 (2003).

52) M. Kosfeld, M. Heinrichs, P. J. Zak, U. Fischbacher \& E. Hehr: Nature, 435, 673 (2005).

53) A. MacFarlane: in "Parent-infant Interactions", Ciba Found. Symp. 33, 1975, p. 103.

54) L. Righard \& M. O. Alade : Lancet, 336, 1105 (1990).

55) M. Kaitz, A. Good, A. M. Rokem \& A. I. Eidelman :Dev. Psychobiol., 20, 587 (1987).

56) A. S. Fleming, C. Corter, P. Franks, M. Surbey, B. Schneider \& M. Steiner : Dev. Psychobiol., 26, 115 (1993).

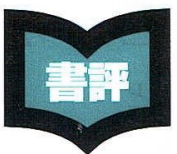

遺伝子 第 8 版

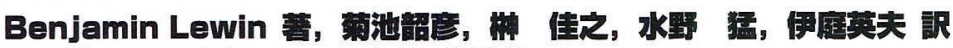 \\ A4 判, 952 面, 10,500 円 (税远) \\ 東宗化学同人, 2006 年}

本書は, Benjamin Lewin 博士の名著『GENES』第 8 版 の日本語訳である. まず，B5 判から A4 判に改訂されてい ることに新鮮さを感じた. 次に, 初版からすでに四半世紀 む経ったのかというある種の感慨. 実は, 以前に 3 年ほど 本書の英語版を大学院の授業の教科書として使っていたこ とがある. 評者の実力と 15 回という講義回数の制約から, とても全部を講義できるわけではなかったが, 大変な勉強 になった記憶がある。 それだけに，本書にはある種の懐か しい思いもある.さらに，7版の時もそうであったが，8版 の原著が出版されて 2 年足らずの間に日本語訳が出たわけ であり, 翻訳にあたられた先生方の弛みない努力に頭が下 がる.

早速中をめくってみると, 7 版と同様, 8 版でも I 部から 第 VI部までの 6 部構成であるが, 第 7 版が 6 部 29 章で あったのに対し，8版は 31 章に増えている. 第血部に「遺 伝子発現調節」という 1 章が加わったことと, $\mathrm{V}$ 部に「ク ロマチンの構造を調節する」という章が加わったためであ る. そうした改訂のためと思われるが，7版の各部の夕イ トルが,「遺伝子」,「タンパク質」,「mRNA」,「DNA」, 「核」「細胞」であったのに対し，8版では而部のタイトル が「遺伝子発現」と変わっていたり，I 部やV部を構成す るいくつかの章のタイトルも違ったものになっている，ま た，図が本文の中にちりばめられていた 7 版と違って，8 版ではそれぞれのページの外側に図のための専用のスペー
スをゆったりと取っている．このことにより，非常にすっ きりとして見やすくなり，上品な感じを与える本となっ た. さらに, 7 版と違い, それぞれの章の初めに各節のタイ トルがまとめて記述されていて，また各節の最初に数行の 要約が囲み記事のような形で記述されている.すずての図 の上に，その図で著者が読者に言いたいことが赤い背景の スペースに短くまとめられてむいる。こうした読者のこと を考えたいくつかの新しい編集スタイルが，8版に新しい 本のような印象を与えている.

今回の改訂の特徴は, 多くの生物のゲノムの全塩基配列 が決定されたことから得られた最新の情報を全体にわたっ て取り入れたことにあるが，まさに，絶え間なく進化し続 ける「Lewinの GENES」ということができる. 20 年前の 著者の思想は,「遺伝子」という視点から，生命現象を原核 生物, 真核生物にかかわらず統一的に理解するということ であったと思われる，20年の間に，ゲノムの時代が到来 し，たとえば，T. A. Brown 博士の大胆な試みの教科書 『GENOMES』のような,「ゲノム」を出発点として生命, あるいは生命システムを理解しようとする新しい試みの教 科書も出版されている。しかし，いかにゲノム情報を取り 入れる改訂を行なっても, 生命現象は「遺伝子 (GENES)」 を主軸にした観点から統一的に理解できる，という著者の 思想は微塵む変わっていないように感じられる。

（原島 俊） 